OPEN ACCESS

Edited by:

Mirjam Ros,

University of Amsterdam, Netherlands

Reviewed by:

Wil De Jong,

Kyoto University, Japan

Margaret McCall Skutsch,

Universidad Nacional Autónoma de

México, Mexico

${ }^{*}$ Correspondence:

James Douglas Langston james.langston@my.jcu.edu.au

Specialty section: This article was submitted to

People and Forests,

a section of the journal

Frontiers in Forests and Global

Change

Received: 08 November 2018

Accepted: 18 February 2019

Published: 19 March 2019

Citation:

Langston JD, Riggs RA, Kastanya A

Sayer J, Margules $C$ and

Boedhihartono AK (2019) Science Embedded in Local Forest Landscape Management Improves Benefit Flows

to Society.

Front. For. Glob. Change 2:3 doi: 10.3389/ffgc.2019.00003

\section{Science Embedded in Local Forest Landscape Management Improves Benefit Flows to Society}

\author{
James Douglas Langston ${ }^{1,2 *}$, Rebecca Anne Riggs ${ }^{1,2}$, Agustinus Kastanya ${ }^{2,3}$, \\ Jeffrey Sayer ${ }^{1,2,4}$, Chris Margules ${ }^{1,2,5}$ and Agni Klintuni Boedhihartono ${ }^{1,2,4}$ \\ ${ }^{1}$ Centre for Tropical Environmental and Sustainability Science, College of Science and Engineering, James Cook University, \\ Cairns, QLD, Australia, ${ }^{2}$ Tanah Air Beta, Bali, Indonesia, ${ }^{3}$ Department of Forestry, Pattimura University, Ambon, Indonesia, \\ ${ }^{4}$ Faculty of Forestry, Forest Sciences Centre, University of British Columbia, Vancouver, BC, Canada, ${ }^{5}$ Institute of \\ Sustainable Earth and Resources, Faculty of Mathematics and Natural Sciences, University of Indonesia, Depok, Indonesia
}

There is a global shift of forest management to local levels to better reconcile local livelihoods and biodiversity conservation. We argue that achieving such outcomes will require embedding science in landscape-scale management systems. We show that science can contribute to local learning and adaptation within landscape contexts. Complexity and power relations have hampered scientists' efforts to engage with the people who use and influence the use of resources at landscape scales. Landscape approaches present an opportunity for science to help steer local management to address local contexts. We have conducted research at the interface of policy and management at landscape scales. More effort must go toward transdisciplinary approaches to co-generate knowledge and create "Communities of Commitment" for continual learning and adaptation amongst landscape-scale actors. Embedded science incorporating local knowledge and contexts and engaged in landscape scale development processes is necessary for improving decision and policy-making.

Keywords: landscape approaches, sustainability science, conservation science and society, research in development, local management, transdisciplinary action-research

\section{INTRODUCTION}

Place-based sustainability science and transdisciplinary research have contributed to a better understanding of development processes (Mauser et al., 2013; Balvanera et al., 2017). Understanding that the environment, society, and economics are dynamic and inexorably linked is the foundation of scholarly interest in social-ecological systems (Guerrero et al., 2018). The links in systems, identification of system tipping points, and ways to achieve more sustainable transformations must be understood if science is to foster more sustainable and inclusive development (Wiek et al., 2012). However, despite a proliferation of initiatives, the adoption of a social-ecological systems perspective is far from delivering on its potential, especially in the dynamic forest landscapes of the tropics (Blythe et al., 2018; Guerrero et al., 2018).

The contexts for applied place-based transdisciplinary research are changing rapidly (Brondizio et al., 2016). Recently, sustainability science and transdisciplinary research have been applied to the management of social-ecological systems. This embedded and applied research has enriched narratives of "who" decides what the problems are and "who" provides solutions and at what scale (van Noordwijk, 2017; Blythe et al., 2018; Opdam, 2018). The changing contexts lie in 
global shifts to decentralize forest management and to acknowledge and legitimize local forest rights (Persha and Andersson, 2014; Fisher et al., 2018). In the tropics, forests allocated for local community management are expanding more rapidly than those allocated for strict protection. Nearly a third of forests in developing countries are now under some form of local control, more than twice the area allocated for strict protection (Chape et al., 2005; Schmitt et al., 2009; Peres, 2011; Rights and Resources Initiative, 2014). The UN Declaration on Forests and the Tropical Forest Alliance explicitly advocate community management to avoid deforestation. The following quotes illustrate the enthusiasm with which development and conservation organizations support this shift in management.

\footnotetext{
"There is no better way to ensure the careful stewardship of [forests]-whether in the Amazon basin, the Andean highlands or the jungles of Central America-than to give indigenous communities full control over the land"

Moreno (2016) (President of the Inter-American Development Bank).

"Community control of forest lands is a gift that keeps on giving"

Union of Concerned Scientists (2013).
}

Inclusion of local people is required to satisfy global commitments to sustainable development as expressed by the 2030 Agenda for partnership, people, planet, peace, and prosperity (Colglazier, 2015; Gupta et al., 2015). To exclude local people would be to deny their human rights and the strong relationship local people have with their environments (Berkes, 2004; Liu et al., 2007; Inman, 2016; Langston et al., 2017). A rich history of analysis of local governance and resource stewardship has informed decisions and policies to acknowledge and legitimize localized resource management regimes (Nagendra and Ostrom, 2012; Ostrom, 2015). Local management regimes are highly diverse (Gilmour, 2016), from passive participation in programs, along a spectrum of increasing engagement to full active control. Recognition that the fate of forests ultimately lies in the hands of local people is driving the process of decentralizing management (Singer and Giessen, 2017). However, recent studies on locally managed lands raise uncertainty about their contribution to meeting global conservation goals. This in turn raises the question over how science can best contribute to achieving sustainability and inclusivity of social-ecological systems management (Robinson, 2006; Sikor, 2006; Wiersum et al., 2013; Jong et al., 2015; Schusser et al., 2015; Bhagwat and Humphreys, 2017; Sayer and Margules, 2017).

Contemporary science is slowly embracing sustainability science based on collaborative, transdisciplinary approaches and social-ecological systems thinking, and is working at the landscape scale to make impact (Opdam, 2018). Yet large disconnects between local realities, conservation science and practice, and global policy discourses suggest an unmet need to science Robinson (2006); Boedhihartono et al. (2018); Bull et al. (2018). Global environmental discourses justify policy interventions that do not harmonize with local realities (Adger et al., 2001; Bull et al., 2018). Policy emerges from narratives and discourses rather than from objectively weighed evidence (Pawson, 2006; Shanahan et al., 2011). Science must engage influential actors and knowledge systems to influence narratives at the scale at which interventions take place.

In this paper, we describe the use of embedded science to influence narratives in a direction that increases commitments to sustainability. We define embedded science as the cogeneration and integration of knowledge across disciplinary boundaries, into the pre-existing actor networks that affect landscapes. Landscapes are considered social-ecological systems, delimited by a set of locally identified problems (Sayer et al., 2013; Opdam, 2018). Our cases draw on concepts from place-based transdisciplinary research and sustainability science (Lang et al., 2012; Brandt et al., 2013; Balvanera et al., 2017). As governance complexity increases and local management regimes are more widespread, we strategically position our science to co-generate the knowledge needed to make effective management decisions at local scales (Mauser et al., 2013).

Embedded science heeds the call from van Noordwijk (2017) for research "in" development. Research in development is conceptually different to research "for" development or research “on" development (Coe et al., 2014). Research on development implies separating the researcher from the subject, research for development is a more linear pass-the-baton approach (Thornton et al., 2017). Embedded science or research "in" development is collaborative and supports the co-generation of knowledge with a full range of disciplines and partners. Embedded science requires that researchers have a "seat at the table" alongside the actors who debate policies and programs.

The recent trend toward local management provides an opportunity to examine relationships between science, policy, and management. Local management creates the need for effective multi-level and polycentric governance (Bixler, 2014; Alexander et al., 2016). In this paper, we describe challenges and opportunities for co-generating knowledge with the multiple actors that influence local decision-making (Lang et al., 2012; Polk, 2014). We show that scientists must be flexible, reflective, and reflexive in their roles and approaches if they are to influence the ways in which local management regimes deliver conservation and development impacts (Evans et al., 2017; Boedhihartono et al., 2018; Ros-Tonen et al., 2018). Finally, we identify some practical methods to embed science and describe lessons from our work as part of our approach to conducting research in development, rather than on development.

\section{CHALLENGES FOR EMBEDDED SCIENCE}

Governance processes that move the locus of control to the community level may divert attention away from the need to manage for public goods values of forests such as biodiversity and stored carbon (Ostrom, 2015). If landscapes are going to deliver the multiple services required of them (Fischer et al., 2017), conservation and development organizations must be receptive to knowledge from the full range of disciplines (Wiek et al., 2011). Currently, we observe that there is too little commitment by scientists to gaining the understanding of local contexts required 
to create the knowledge to place forest landscapes onto more sustainable trajectories (Chambers, 2012).

\begin{abstract}
When researchers position themselves strategically within landscape management processes and adopt an action-research approach, they can gather data and influence the process at the same time. In this way, research can help meet the needs of practitioners and policymakers, while practitioners and policymakers will help in answering relevant research questions (Kusters, 2015).
\end{abstract}

Effectively embedding science is impeded by the rigidity of institutions that conceptualize and transfer scientific knowledge. We classify these challenges into four domains; system complexity, epistemology, institutional stickiness, and power distributions. We identify how science can better address these challenges in forest-landscapes.

\section{Complexity}

Complex institutional arrangements that struggle to resolve trade-offs between conservation and production are the normconflicts of interests are inherent in forest landscapes. For instance, local people asserting their rights to self-determination often consider that their short-term needs to clear forests for agriculture or to hunt and $\log$ in forest areas have greater legitimacy than externally imposed conservation goals. This complexity is rooted in the how landscapes are socially constructed; they have unique spatial "identities" (Davenport and Anderson, 2005; Massey, 2005). Landscape identity and distinctiveness is shaped not only by externally perceived functions, but also by the social and cultural capital of a landscape's inhabitants, which is reproduced through stories and memories (Buizer and Turnhout, 2011). As technological developments and socio-cultural contexts change, these traits are not static. Landscapes are therefore sites of subjective experiences which are constantly evolving (Arts et al., 2017). For scientists aiming to influence landscapes, the complexity and history of "territorialization," or processes by which culture and nature interact and co-produce landscapes (Horlings et al., 2016), merits greater attention. Akin to people learning languages, scientists can benefit from immersing into place, to be conversant with local discourses that shape and influence place.

Scientists need to understand the institutionalization of cultural phenomena in landscapes. These are the rules that determine modes of operating-including the routines, organizations, and ways of cooperation through which landscape governance operates (Arts et al., 2017). Governance arrangements are polycentric and often emerge through "institutional bricolage" (Cleaver, 2017). This complexity alone demands different patterns of scientific engagement in different locales. Scientists can become part of networks of influence and define problems in partnership with those whose behaviors they seek to change.

"Context is everything" (Sayer and Margules, 2017). Placebased approaches recognize that complexity manifests in the diverse and changing perspectives people hold of their place. A seeming paradox of place-based science is that there are no generalizable findings due to the complexity of places. Results from a study of one landscape are rarely transferrable to another landscape. There are not enough resources-scientists, funds, and time, for place-based science in all locations. Yet this complexity is precisely the reason that embedded science is needed.

The transferability components of embedded science are the ways in which hypotheses are developed and tested, and the analytical methods adopted. As such, embedded science is about getting the questions (or hypotheses) right and improving methodological applications to influence the narratives and power distributions that steer decision making within a landscape. The present movement to hand over forest management to communities without ensuring that appropriate mutual obligations, governance arrangements, and checks and balances are in place could lead to a depletion of forest biodiversity (Laurance et al., 2011; Langston et al., 2017; Terborgh and Peres, 2017). Local forest management initiatives that are not rooted in fundamental principles of sustainable forest management and do not harmonize with local governance arrangements and capabilities risk failing to achieve socioeconomic or ecological gains.

\section{Epistemology}

Policy makers and implementing agencies do not make decisions based primarily on evidence (Mintzberg and Westley, 2001; Pawson, 2006). Rather, they make decisions based on the narratives formed in the social and political networks in which they operate (Keeley and Scoones, 2014). This can result in "policy-based evidence" (Marmot, 2004), wherein implementing agencies allocate resources based on the agendas of those with whom they communicate, share knowledge or perceive as influential. Similarly, we know that scientific findings do not usually "fall on blank minds"; instead, science interacts with occupied minds that have strong views about how things are and should be (Marmot, 2004; van Noordwijk, 2017). Funding constraints may compromise the scope of scientific activities that are possible and further bias strongly held views, reinforcing the narratives emerging from their research (Wunder et al., 2008; Redford et al., 2013).

Scientists are often not sufficiently epistemologically agile (Haider et al., 2018) to maintain and bridge dialogues between policy makers and implementing agencies. Forest landscapes are complex social-ecological systems that demand collaborative transdisciplinary problem framing (Brondizio, 2017; Law et al., 2017; van Noordwijk, 2017). Inflexible epistemology is an obstacle if science is to engage effectively with the multiple knowledge systems interacting with diverse actors that operate at local levels (Chambers, 2014b). There is an enormous diversity of epistemological and ontological traditions affecting the exchange and translation of information. Berkes (2012), in a review of the philosophy of science, stylizes ontological differences between local knowledge and western science. He characterizes local knowledge by human-nature inseparability, subject, and object inseparability, and experiential learning. In contrast, he characterizes western science as compartmentalizing variables and relying on reductionist experimental learning. Compartmentalization of different components of earth systems is manifest in multiple ways that societies function, none more so than in the ivory towers of academia. 
The relative legitimacy of natural vs. social science and qualitative vs. quantitative information continues to divide disciplines and inhibit progress (Sunderland et al., 2007). Questions of what entails legitimate knowledge present challenges for how academia engages with the non-disciplinary domain of conservation \& development (Pressey et al., 2017). In terms of sustainability, different disciplines have coalesced around discourses of resource rights, human justice, inclusivity, and environmental sustainability (Nijnik et al., 2014; Cashore et al., 2016; Riggs et al., 2016; Dawson et al., 2017; Humphreys et al., 2017). However, "traditional analytical frameworks," where ontologies are static and linear, are a weak tool for solving complex problems in landscapes (Duit et al., 2010). Landscapes are heterogeneous and scientific engagement should legitimize and integrate with multiple actors, knowledge systems, stakeholders, and decision-makers (van Noordwijk, 2017). Transdisciplinary research in sustainability science offers opportunities to mobilize scientific capacity in a more democratic way (Brandt et al., 2013).

More obstacles to knowledge integration lie in collective human cognitive capacity. Behavioral scientists show that the more nuanced messages do not get the same traction as simplistic statements due to deficits in today's attention economy (Davenport and Beck, 2001; Tufekci, 2013). Rapidly expanding knowledge, and the increase in misinformation and disinformation compete for attention (Chambers, 2014b). Thus, attention is restricted to sound-bites, simplistic, and polarized messages (Ciampaglia et al., 2015). Rapid technological growth is testing societies' cognitive abilities to sift through vast amounts of information to comprehend the nuances surrounding issues (Friedman, 2017). Scientists face similar difficulties; the sizeable growth of peer-reviewed literature over the past decades means scientists may overlook papers contributing to more nuanced understanding of their fields (Courchamp and Bradshaw, 2017). This contributes to narratives that steer decision-making that are contradictory or disconnected from complex realities.

\section{Institutional Stickiness}

While concepts and calls for collaborative science to deliver societal learning are not new, their efforts have been hindered by institutional stickiness; the inability for new institutions to take hold in a setting of suboptimal institutional arrangements (Hajer, 2003; van Oosten et al., 2017). Organizations have thus far been too conservative in their approach to both partnering locally for the co-generation of knowledge and to sustaining natural resources (Sundar, 2000). Their bureaucratic institutional inflexibility, with myriad compliance requirements, inhibits the creation of innovative relationships and networks that influence system wide learning (Scheba and Mustalahti, 2015). Furthermore, high transaction costs of inter-institutional coordination lead to fragmented governance; many conservation and development organizations work side by side but with minimal cross-scale and cross-sectoral communication (Giessen, 2013; Gallemore et al., 2015; Sahide and Giessen, 2015; Riggs et al., 2018a). Collaborative management initiatives must avoid top-down control and instead be based on a platform of power equality (Sundar, 2000).
Transdisciplinary teams are subject to funding constraints (Wunder et al., 2008). If funders require deliverables framed by institutions that are not rooted in local contexts, bottomup problem framing will be hard to achieve. Harmonizing work to local realities must involve changes in donor behaviors so that downward accountability is mainstreamed (Ebrahim, 2003). To achieve this, leadership in organizations that deliver funding can promote deliverables that include rigorous diagnoses of the social-ecological systems in which the work is to take place. Research questions should be included and aimed at strategizing how the organization can better embed their work inclusively and appropriate to local development settings, needs, and aspirations.

In the 1990-2000s, adaptive collaborative management (ACM) received attention for its potential to deliver better social learning outcomes for governing complex social-ecological systems (Armitage et al., 2009). ACM is a process where multiple stakeholders bring together their different knowledge, experiences, perspectives, values, and capacities to communicate and critically reflect to understand and address common concerns (Khadka and Vacik, 2008). It acknowledges that reaching consensus on what the problems are and acting to implement policy decisions requires change in multiple actors in any given social-ecological system. Better coordination requires an understanding of the value systems of these actors and searching out intersections of interests. Negotiating around these intersections of interests must be incorporated into decisions about the future (Biggs et al., 2011). In many cases, required behavioral changes must emerge from decisions made by local resource users, but will also include changes in government policies and programs and changes in investments made by the private sector. In order to promote change in all of these actors, it is necessary to understand the values and motivations of decision makers and to communicate with them (Bennett et al., 2017). Too many scientists see the challenge of communication as being the challenge of delivering a message to decision-makers based on the results of their research; one-way communication telling decision-makers the results of studies. In fact, the challenge for scientists is to listen to and learn from the people who might benefit from their research.

Many organizations prioritize scientific methods based on the "gold standards" of randomized controlled trials, which, in complex dynamic landscapes, can mislead or fail to provide the evidence upon which conservation decisions should be made (Agrawal, 2014). We join others who observe how projects and externally planned conservation initiatives might displace landscape management capabilities based on long periods of unstructured experimentation or trial and error, which may be more likely to lead to conservation success (Hodge and Adams, 2016; Pressey et al., 2017). Experience suggests that global policy and decision-making institutions need to build their collective resilience through more learning-based and flexible approaches that draw on diverse and collective wisdom (Fisher et al., 2017). Effective governance includes the transfer of authority, transparency, and upward and downward accountability, and much of this hinges on knowledge dissemination (Khatun et al., 2015). This does not mean outcomes will be predictable 
because local contexts demand different decisions and management interventions.

\section{Power Relations}

Local power arrangements are difficult to understand, and it may be difficult for outsiders to engage with them. To locals, poor-transparency and corruption in resource allocation decisions occur when opaque governance arrangements inhibit accountability. Power arrangements are the determining factors in who decides local landscape conservation and development outcomes. Embedded science must deliver where traditional science has not-in the failures to engage people, especially those people who live in, use, or otherwise influence the use of resources where sustainability outcomes are at stake (Mcnie, 2007; Knight et al., 2008). Power distributions must be confronted, understood, and dealt with if science is to make any difference (Riggs et al., 2018b).

The exclusionary nature of professionalism and entrenched rigid bureaucratic policies promote compliance over systemic learning (Green and Lund, 2015). Donor organizations and project planners have prioritized formalizing joint management processes, leading to a "professionalization" paradox (Lund, 2015). Professionals are seen by locals as external experts who micromanage local efforts by setting up multiple participatory committees, which often do not align with local expectations for the future (Scheba and Mustalahti, 2015). We see ongoing failures from professional experts meeting donor requirements by handing over knowledge they believe should be used to implement change, re-creating the flaws of formally planned and highly modernized science endeavors (Mintzberg, 1994; Scott, 1998).

Participatory action research aiming to underpin collaborative management has been beset by problems characterized by a tyranny of participation. Promoters of participatory methods claimed that participation would challenge hegemonic practices by empowering development beneficiaries to determine the direction of change (Enns et al., 2014). Participation can be misused-a social tool turned into a social weapon. While participation began as a counter-hegemonic concept, it has been used in "very hegemonic ways" (Enns et al., 2014). In their book Participation: The New Tyranny? Cooke and Kothari (2001) argue that participatory schemes often fail to engage with issues of power and politics, depoliticizing what will always be political processes. Further, there have been numerous cases where collaborative schemes serve to legitimize decisions already made, resembling the "we manage, you collaborate" approach, or where participation is used by organizations to make their projects and activities more cost-effective by drawing on communities' own resources (Gaynor, 2013).

Proponents of participatory approaches still assert that meaningful participation has potential to equalize power relations between intended development beneficiaries and experts (Kusters et al., 2018). If scientists are going to contribute to socially just power arrangements, they must avoid involving local actors simply to share operating costs. They must be proactive in paying careful attention to the existing cultures and practices into which their work is to be introduced and take precautions about how to interact with actor-networks of power and politics. There is inherent epistemic privilege associated with academia, and as such, the authors of this paper agree with recent pleas for better reflexivity among scientists (Popa et al., 2015). This includes understanding the need to cede control of problem framing and aim for contributions that redistribute power throughout the system for inclusivity and sustainability.

\section{A WINDOW OF OPPORTUNITY}

The recent and ongoing allocation of significant areas of forest to local management provides a window of opportunity for science to partner with local managers and co-generate knowledge. Multiple scholars are concerned that the present movement to hand over forest management to communities without ensuring that appropriate governance arrangements and science-based management regimes are in place could lead to the depletion of forest biodiversity (Laurance et al., 2011; Langston et al., 2017; Terborgh and Peres, 2017). "Local science" in its various forms is an important contributor to solving highly specific, context dependent problems (Danielsen et al., 2005; Sayer et al., 2015; Sutherland et al., 2015; Dawson et al., 2017). Local and indigenous knowledge should complement and be inter-woven (Tengö et al., 2017) with academic science, fostering transdisciplinary understanding of complex social and ecological contexts. In tropical forested landscapes, more often than not, conservation and development initiatives are still a top-down exclusionary process (Sheil, 2017). More frequently, local people assert their rights to self-determination and often consider that their short-term needs have greater legitimacy than externally imposed public good conservation goals. Cogenerating knowledge will mean that they facilitate and are a part of the narratives and networks that influence change (Nel et al., 2016).

Opportunity also lies in the proliferation of landscape approaches (Reed et al., 2016). Society's biggest endeavors to reconcile conservation and development, and even more broadly to achieve sustainable development, are now claiming to use a decentralized landscape approach (Erbaugh and Agrawal, 2017). Landscape approaches are the current iteration of integrated conservation and development initiatives and have been conceptualized as a set of principles, guidelines, and tools for adaptive conservation (Defries and Rosenzweig, 2010; Sayer et al., 2013; Reed et al., 2016). Implementing agencies will not reach their goals by applying "cookie cutter" landscape approaches; science and the co-generation of knowledge will need to be embedded at the landscape level to ensure learning and adaptation leading to capacity building and an extensive cadre of local, naturally-embedded, science-based conservation practitioners. Landscape approaches attempt to tailor conservation to local realities and contexts, yet their impacts remain elusive (Sayer et al., 2016a; Reed et al., 2017). Additionally, they have been criticized for lacking rigorous conceptual frameworks (Erbaugh and Agrawal, 2017) and being used as a means of de-politicizing the problems apparent in social-ecological systems (Mccall, 2016). If these concerns 
can be acknowledged and power politics and underlying narratives addressed head-on, landscapes can be useful arenas in which to experiment and learn about sustainability science in geographic spaces.

Decentralized forest management and landscape approaches offer a window of opportunity for embedded science, but there must be a willingness among scientists to do this. In the next section, we identify recent progress in overcoming challenges of embedded science and methods to foster more inclusive, sustainable development.

\section{SCIENCE TO CO-GENERATE KNOWLEDGE}

Emerging literature on how to contextualize sustainability science to be inclusive of the range of knowledge systems seems promising (Cornell et al., 2013; Mauser et al., 2013). Tengö et al. (2017) highlight five tasks science can undertake to be more inclusive of diverse knowledge systems: (1) mobilize, (2) translate, (3) negotiate, (4) synthesize, and (5) apply multiple forms of evidence. Their framework, by empowering and seeking to bring together diverse actors, explicitly links indigenous and local knowledge systems with science to inclusively enhance governance for sustainability. However, they claim that "tools and approaches that consistently enable engagement toward useable knowledge for all actors involved in these encounters are not yet available." We argue below that various tools including participatory simulation modeling, visualization techniques, and actor network analysis, are useful and can be deployed strategically so that science better embeds itself in local development processes. We assert, however, that more methods are needed to make sustainability science work in "places" in an inclusive way-where the science engages with diverse worldviews, identities and ethics, and addresses rights and power asymmetries. There also needs to be more evidence of their effectiveness in achieving inclusivity and impact.

Butler et al. (2015) provide an example of how scientists might begin to co-generate knowledge using Participatory Systemic Inquiry. Their aim was to enhance adaptive capacity for change. They found that if the process is too researcherdriven, knowledge exchange and production is less effective. They suggest more participatory rural appraisal techniques to address local planning needs. Additionally, they suggest that more nuanced stakeholder analysis and measures to anticipate power dynamics are needed. We suggest that more up-front collaborative problem framing with the kinds of diagnostic tools suggested below might improve science, policy, and management relationships. Influencing policy decisions and their implementation will require changes in the behavior of multiple actors in any given social-ecological system. Thus, the value systems of these actors must be understood, negotiated and incorporated into decisions about the future (Biggs et al., 2011).

Theory of place is a conceptual framework to help scientists cope with multiple forms of knowledge, multiple actors, and power asymmetries in landscapes. It provides a set of useful diagnostic and reflective tools to interrogate the who, what, and where questions that can identify pre-existing inventories of knowledge and narratives in landscapes (van Noordwijk et al., 2015). Theories of change frameworks can help grapple with the relationships in actor networks and processes that drive change. Rigorous theories of change can keep conservation science agencies on track and avoid displacement activities (Pressey et al., 2017). Simulation models and visualization techniques that explore alternative landscape scenarios can help challenge assumptions and make theories of change more rigorous and adaptable to changing circumstances (Collier et al., 2011; Boedhihartono, 2012; Sayer et al., 2016a) Generic theories of change for landscape level processes have been described elsewhere (Sayer et al., 2016a; Thornton et al., 2017; van Noordwijk, 2017). Used in a participatory and flexible way, they serve to clarify leverage points, where scientists can co-generate the knowledge that influences policy decisions and management outcomes. They also serve to identify learning points, where monitoring and reflection on the process can lead to incremental improvements in the system.

Recently Tschirhart et al. (2016) confirmed that peer to peer learning is effective and that effort should be put into identifying, and then strengthening, community owned solutions through peer-to-peer knowledge exchange. Policy, Social, and Actor Network Analysis (Jackson, 2010; Brockhaus et al., 2014; Gallemore et al., 2015) coupled with Actor Network Theory (Valverde, 2007) can provide insight on where scientists can situate themselves to co-generate the knowledge that will influence narratives and behaviors. A thorough understanding of the networks will allow for the identification of the charismatic leadership required for successful partnerships. Recently, Qmethodology has shown potential for uncovering underlying narratives where power and politics drive decisions (Mckeown and Thomas, 2013; Nijnik et al., 2014; Pirard et al., 2016; Amaruzaman et al., 2017). We think these frameworks, tools and methods can assist scientists to engage with the multiple actors and the preexisting multiple knowledge systems within landscapes. Data and data transparency are integral to enabling society to coalesce around knowledge narratives. Scientists must define problems in partnership with those whose behaviors they seek to influence with the evidence they will provide, and the landscape scale has emerged as a manageable entry-point.

Sayer et al. (2016a) show that landscape improvements in learning and adaptation come from process driven approaches geared toward incremental change, as opposed to outcome driven approaches aiming for transformations. In our experience, embedding and influencing actor networks for added inclusivity and enhanced cross-sectoral and multi-level communication have led to better decision making at the landscape levels. Examples with long-term data documenting trajectory of decisions include the Malinau research forest in Indonesia (Wollenberg et al., 2007), and the Sangha Tri-national landscape in West Africa (Sayer et al., 2016b). In the case of Malinau District in Indonesia, forest conservation efforts had to address a weak institutional setting and challenging politics (Wollenberg et al., 2007). Participating actors including conservation scientists and managers recognized they were part of that institutional context, not separate from it. In response, they learned through the political and institutional uncertainty to develop ways of 
cooperating based on regular contact, maintaining a physical presence, staying sensitive to the needs of diverse actors, and being flexible (Armitage et al., 2012). Both cases show how long-term collaborations between different scientists and local knowledge brokers enriched the discussions amongst all stakeholders. The enhanced relationships and discussions allowed for a better understanding of, and adaptation and response to the main drivers of change in the landscapes. The use of theories of change and place, network analysis, and discourse analysis can value add in the long-term strategy for embedded science if these tools are used flexibly to optimize institutional arrangements.

\section{Bridging Epistemological Divides}

Framing and solving complex problems of forest landscapes requires drawing upon a range of disciplines and epistemologies (Wiek et al., 2011). Epistemological differences are difficult to rectify in the bureaucratic structures and incentives for career development that encourage the "fence and defense" attitude to one's research area (Haider et al., 2018). Straddling academia and practice, a growing number of sustainability science practitioners sympathize with Robert Chambers' notion of being ill-disciplined (Chambers, 2014a). The authors of the present paper are a collection of early career researchers, mid and late career researchers and applied scientists, from diverse backgrounds that have all worked to reconcile local vs. global conservation and development values in forest landscapes in the tropics. We label our approach "practical" political ecology. Practical political ecology is where resilience thinking meets political ecology, applied science and transdisciplinarity. Political ecology explicitly aims to bridge the natural and social sciences and address power and scale. Resilience thinking represents the latest in social-ecological systems concepts and frameworks (Brown, 2015). We take the practicality of understanding systems and power politics to mean engaging constructively with actors on the ground, rather than deconstructing how things are from afar.

It would be naïve to expect complete impartiality on behalf of scientists; we are humans with our own ontologies that suggest to us what deserves our attention. To help address this, complexity, systems thinking, and facilitation could become part of a standard science education. Current incentives for early career researchers favor laboratory-based meta-studies, remotely sensed problem diagnosis, and reductionist single species or single factor studies that are readily published in journals (Courchamp and Bradshaw, 2017). The messy real world of rapidly changing forest landscapes challenges science that is driven by simple hypotheses. Systems science (Sayer and Campbell, 2004) and sustainability science (Clark et al., 2011) require deep long-term engagement with diverse stakeholders by transdisciplinary teams focused on addressing the real problems of actors in the landscapes (Balvanera et al., 2017). To address these problems means being a part of networks of influence, working "with people, not on or for them" (Chambers, 2012).

This sort of science usually takes the form of interdisciplinary bodies rather than individual experts. It draws on diverse perspectives to integrate scientific knowledge and policy options and acknowledge uncertainty. It calls for honest brokersindividuals or bodies that seek to widen the range of policy options in a way that allows decision making based on preference and values (Pielke, 2007). Honest brokers exist in contrast to issue advocates that align themselves with a particular political agenda or interest group, often cherry-picking evidence to make the case for their agenda (Huitema and Turnhout, 2009). If scientists act as "honest brokers" rather than "issue advocates," they will likely increase the impact of their findings on natural resource policy-making (Pielke, 2007; Chambers, 2014b).

Honest broker bodies can broker knowledge by forming new hubs of information to serve the needs of decentralized management (IDLO, 2016; Sayer et al., 2016a) These hubs would best serve if they included inventories of knowledge on the full range of assets within a landscape: human, social, financial, physical, and natural. Scientists could build knowledge inventories in collaboration with, and accessible to, other scientists from a range of disciplines, as well as all of the actors in the relevant landscape. More complete and transparent inventories will lead to more representative transdisciplinary problem framing (IDLO, 2016; Brondizio, 2017). Arts and De Koning (2017) have already shown that community forest management will have a greater likelihood of success if local groups are linked by a Community of Practice to diverse groups that include external forest scientists. We suggest that embedded science should drive those linkages and shift Communities of Practice toward "Communities of Commitment." These are communities of collaboration, mutual support, solidarity, and shared inspiration (Chambers, 2012). Communities of Commitment should lead to more specific understanding of problems and their potential solutions.

\section{Trialing Embedded Science}

The authors of this paper are part of a team of researchers and practitioners that try to embed science into local forest landscapes to improve decision-making for better conservation and development trajectories across the tropics. We work in "sentinel landscapes," where we apply landscape approach principles and hope to engage for the long term. Much of our work takes place in Indonesia. We present two contrasting cases where local contexts, resource constraints, and the results of taking the approaches described heretofore have led to different local landscape outcomes. Lessons learned from our previous attempts at collaborative science in Malinau (Gunarso, 2007) the Sangha Tri-national landscape (Sayer et al., 2016b), and Lombok (Riggs et al., 2018a) are informing our attempts to foster embedded science processes in Seram and Riau.

\section{Lessons From Seram, Maluku, Indonesia}

In 2017, our non-government organization, Tanah Air Beta, an association of scientists interested in applying science to achieve productive and sustainable land and seascapes, embarked upon a program to trial a landscape approach on Seram. Our objectives were to diagnose the current issues effecting landscape functionality and determine where coordination and commitment might leverage more sustainable landscape outcomes for both conservation and development. The project 
is funded by a donor, the Critical Ecosystem Partnership Fund, whose mission is to secure the long-term viability of certain endemic species that have led to parts of the island being designated as key biodiversity areas (KBAs). Our approach is to work with local communities and the administration to improve long-term stewardship of natural resources and address problems that are locally diagnosed. We have been returning to Seram for extended periods since early 2017.

Our efforts to embed science started with network analysis of the actors influencing conservation and development outcomes in the region. Actor and policy network analysis helped us come to terms with the complexity of actors and their influences in the landscape. Early analysis showed that government and civil society organizations were operating in parallel silos (Liswanti, 2012). We sought to convene meetings with actors that had not been coordinating with each other, but whose mandates might benefit from better cross-sectoral information sharing and collaboration. Through this process we have begun building consensus for what we hope to be a long-term collaboration with universities, local NGOs, and government agencies identified from that process.

A case of environmental pressures stimulating needs for environmental intervention emerged on one of Seram's small surrounding islands, Boano. There, monoculture development of Melaleuca cajuputi and the demand for firewood to make oil from harvesting melaleuca leaves is degrading the environment and negatively affecting livelihoods. Our interdisciplinary team of students, teachers, and researchers spent valuable informal time living with the local communities, building interpersonal relationships. We collaborated with the local natural resource management (NRM) organization Lembaga Partisipasi Pembangunan Masyarakat (LPPM) and organized numerous discussions with the different community groups. To understand context in a communication style that was more inclusive we used visualization methods (Boedhihartono, 2012) to co-construct inventories of historical change data, and current and future scenarios of landscape change. These methods opened up discussions about the memories and stories that shape the local landscape identity. We developed an understanding of their environmental, social, and political pressures. We have since began working with LPPM and local leaders to co-produce a landscape development strategy. This continues, iteratively, to involve village meetings where, with our partners, both local and international NGOs, and leaders from the provincial University (Universitas Pattimura or UNPATTI), and relevant district and provincial level government authorities, we have started the messy democratic debates over the future of development in Boano.

A difficulty with this work has been addressing the slow variables of change while meeting 2 year project cycle deliverables. Though we have started co-constructing theories of change with local partners, these do not synchronize with normative project deliverables. Bureaucratically heavy "terms of reference" for our engagement require certain deliverables that do not create a space for institutional bricolage, in which bottom-up processes drive optimal institutional arrangements.
In documenting these processes, we shall strive to influence downward accountability beyond the duration of our project, ensuring future activities by the donor are less top-down driven, and more appropriate to local socio-political conditions. We prioritize processes that will lead to long-term institutional coordination, recognizing the diverse and dynamic needs of local communities. We are wary of unrealistic expectations of actions such as village agreements to guarantee conservation. Specifically, we are conscious of social wounds from past violent conflict that contributed to the degradation of resources and poor governance. While this limits our capacity to monitor progress, we accept this as a short-term trade-off and seek to develop accountability mechanisms for resource use improvements with local partners as we continue.

Our constraints led us to changing our strategy from being prominent conveners, to zooming-in and out as "peripheral agents." This strategy emerged from a collaborative theory of change process, done with local organizations identified in the network analysis. Peripheral agents implement change by brokering trust between centrally located "motivators" or influential actors (Andrews et al., 2017). Being peripheral involves being a less prominent convener or bridging organization (Kowalski and Jenkins, 2015). It involves fostering better connections with influential groups and more effectively mobilizing their engagement with one another. As we recognize our limitations in influencing the politics and market forces driving investments in Seram, we engaged at higher levels to open up information sharing networks and cultivate relationships with government authorities responsible for allocating development resources and developing spatial plans. Through this time, we have continued supporting local partners, maintaining face-time to improve our trustworthiness as "honest brokers" with local communities as opposed to taking control of the problem and solution making process. As peripheral agents, we are strategic in convening participation in ways to avoid falling into the trap of a tyranny of participation as described in the Power Relations section above. We rely on and supplement the capacity of the institutions that evolved from conflict resolution to NRM related activities-a kind of institutional bricolage.

In the process we have shed light on issues that were unseen by political leaders and decision-makers. We have reacted to local power arrangements by maintaining a position of interest in the place, rather than side with political or sectoral interests. We can safely claim success in breaking down some institutional barriers between actors in the network. Cooperating with local NRM institutions ensures that we make progress toward donor driven goals of improving resource management, while focusing our efforts on facilitating better environments for bottom-up driven development strategies. Lessons learned from a previous landscape study in Malinau, North Kalimantan, involved the prominence of strategic government involvement (Wollenberg et al., 2007). In Seram we have made sure to include different influential sectors of the government in the dialogues, problemframing, and strategies for better adaptive and inclusive development plans. 


\section{Lessons From Riau, Indonesia}

Drainage and clearance for oil palm and fiber plantations has had a major impact on the peat swamp forests of Riau Province in Indonesian Sumatra over the past three decades. Protection of remaining forests and restoration of some ecosystems on deep peat are now the object of major investments at a landscape scale. Several small-scale pulp and paper companies are involved in the initiative, which is led by the APRIL (Asia Pacific Resources International) Group. In 2013 APRIL established the Restorasi Ekosistem Riau (RER) to protect and restore 150,000 hectares of peat swamp forest on the Kampar Peninsula. Part of this process included the creation of a Stakeholder Advisory Committee (SAC) comprising of independent forestry and social experts to advise and monitor progress toward APRIL Group's sustainability goals. The Committee performs three crucial roles of embedded science; it provides a platform for scientists to engage with stakeholders, it enables system-wide learning through improved transparency and communication, and committee members act as honest brokers, using an independent verification auditor to monitor progress. In contrast with Seram, the landscape approach in Riau is driven by an industrial corporation. There are inherent power imbalances in the landscape, but independent verification creates opportunities for science to draw attention to these issues and respond to them through stakeholder negotiations and communication. APRIL funds supporting the work do not have strings attached, as in the above case. Instead, they offer a comparative advantage of long-term well-funded commitment (the ecosystem restoration concession is licensed for 60 years, with a commitment by APRIL of USD100 million for the first 10 years), with financial and reputational incentive to achieve a well-functioning landscape.

The first phase of the landscape initiative in RER included excellent scientific analysis of the spatial patterns of land use to develop ideal scenarios for biodiversity conservation in the landscape. However, initial attempts to outsource the landscape diagnosis and planning to an international conservation NGO failed to achieve impact on the ground. These ideal landscape plans had little traction with local land managers who were responding to short-term imperatives. Change in the landscape results from multiple decisions of numerous local landholders and officials. Improving the performance of the landscape in delivering societal benefits requires that science should influence all of these multiple decisions. The dispatch of an ideal map of the landscape- "To Whom It May Concern"-did not achieve the desired outcome.

To improve collaboration with local landholders, the RER management team conducted a second phase of the landscape analysis. Managers of the landscape, the people taking daily decisions on plantation establishment and silviculture, were in daily contact with other landscape stakeholders. They recognized that landscape stakeholders controlled the resources necessary to change the landscape. The managers from the companies and scientists had seats at the decisionmaking table and were able to negotiate with the full range of operators intervening in the landscape. This did not lead immediately to an ideal landscape outcome but it did enable sharing of knowledge and concerns. Committee members were able to advise on appropriate action and strategic direction, while ensuring the negotiation process remained in the hands of the stakeholders themselves. In close proximity to companies and policy makers, scientists brokered knowledge between the multiple levels of decision makers, maintaining cohesion between local landscape needs and broader sustainability principles.

In 2017, we brought together landscape practitioners from both landscapes, among other Indonesian landscapes facing sustainability issues together to learn about the challenges and opportunities for improved landscape sustainability. We performed a discourse analysis using Q-methodology to make the values and perspectives that people hold from both places more transparent (Langston et al., 2019). The results of which show how poor governance is the main motivating factor for pursuing landscape approaches that involve further embedding science to influence the narratives that drive political decision making in both places. One clear message is that embedding science means accounting for and addressing diverse political vantage points. Since then we have been forming a community of practice of scientists partnering with private sector, political departments, and civil society organizations. This ongoing venture is funded by the Tanoto foundation, a foundation set-up by the umbrella company of APRIL, Royal Golden Eagle.

Still in its early stages, the landscape initiative in Riau continues to foster negotiations between needs of local stakeholders, government requirements and business sustainability. A radical transformation to an ideal landscape based on external science proved impossible. Deep engagement of company scientists with local land managers did enable incremental improvements in landscape performance. The lesson is that ideal science-based plans may be less influential than embedded scientists with "skin in the game" and a seat at the negotiating table.

\section{CONCLUSION}

Local management has the attention of governments and scientists. In the context of this relatively recent attention and the related decolonization of management systems, there is a window of opportunity for scientists to become more integrated into local management processes as honest brokers, reflexive in their role and position in society. Scientists interested in influencing how society-nature relations can be improved should endeavor to collaboratively problem frame and co-generate knowledge that steers local activities toward policy and management decisions based on that knowledge. Local forest management initiatives that do not harmonize with local governance arrangements, capabilities, and learning mechanisms, risk losing any socioeconomic or ecological gains that might have been achieved through local management. If scientists are to influence local forest landscape development trajectories, they must become part of the networks of influence. This will require diagnosing institutional arrangements, being inclusive of the perspectives and knowledge types of actors influencing local forest landscapes and partnering with local knowledge institutions and processes 
for continual learning. There are emerging approaches to help diagnose and nudge narratives toward better sciencepolicy-management regimes. We have adopted a series of sentinel landscapes where we work with local partners to cogenerate knowledge to learn from and influence the behavior of resource dependent people. Two of these are summarized above. We seek to join the other agents of change in these landscapes (Sayer et al., 2016a). Academic scholarship should allow for embedded landscape science that can drive a process of negotiation, consensus building, and behavioral change (Pressey et al., 2017).

\section{AUTHOR CONTRIBUTIONS}

$\mathrm{JL}$ wrote the manuscript and conceived of the paper. All other authors contributed to the conceptual framing and provided examples from their personal experience.

\section{REFERENCES}

Adger, W. N., Benjaminsen, T. A., Brown, K., and Svarstad, H. (2001). Advancing a political ecology of global environmental discourses. Dev. Change 32, 681-715. doi: 10.1111/1467-7660.00222

Agrawal, A. (2014). Matching and mechanisms in protected area and poverty alleviation research. Proc. Natl. Acad. Sci. U.S.A. 111, 3909-3910. doi: 10.1073/pnas.1401327111

Alexander, S. M., Andrachuk, M., and Armitage, D. (2016). Navigating governance networks for community-based conservation. Front. Ecol. Environ. 14, 155-164. doi: 10.1002/fee.1251

Amaruzaman, S., Leimona, B., van Noordwijk, M., and Lusiana, B. (2017). Discourses on the performance gap of agriculture in a green economy: a Qmethodology study in Indonesia. Int. J. Biodivers. Sci. Ecosyst. Serv. Manage. 13, 233-247. doi: 10.1080/21513732.2017.1331264

Andrews, M., Pritchett, L., and Woolcock, M. (2017). Building State Capability: Evidence, Analysis, Action. Oxford, UK: Oxford University Press. doi: 10.1093/acprof:oso/9780198747482.001.0001

Armitage, D., de Loë, R., and Plummer, R. (2012). Environmental governance and its implications for conservation practice. Conserv. Lett. 5, 245-255. doi: 10.1111/j.1755-263X.2012.00238.X

Armitage, D. R., Plummer, R., Berkes, F., Arthur, R. I., Charles, A. T., Davidson-Hunt, I. J., et al. (2009). Adaptive co-management for socialecological complexity. Front. Ecol. Environ. 7, 95-102. doi: 10.1890/ 070089

Arts, B., Buizer, M., Horlings, L., Ingram, V., van Oosten, C., and Opdam, P. (2017). Landscape approaches: a state-of-the-art review. Annu. Rev. Environ. Resour. 42, 439-463. doi: 10.1146/annurev-environ-102016-060932

Arts, B., and De Koning, J. (2017). Community forest management: an assessment and explanation of its performance through QCA. World Dev. 96, 315-325. doi: 10.1016/j.worlddev.2017.03.014

Balvanera, P., Daw, T. M., Gardner, T. A., Martín-López, B., Norström, A. V., Speranza, C. I., et al. (2017). Key features for more successful placebased sustainability research on social-ecological systems: a Programme on Ecosystem Change and Society (PECS) perspective. Ecol. Soc. 22:14. doi: 10.5751/ES-08826-220114

Bennett, N. J., Roth, R., Klain, S. C., Chan, K., Christie, P., Clark, D. A., et al. (2017). Conservation social science: understanding and integrating human dimensions to improve conservation. Biol. Conserv. 205, 93-108. doi: 10.1016/j.biocon.2016.10.006

Berkes, F. (2004). Rethinking community-based conservation. Conserv. Biol. 18, 621-630. doi: 10.1111/j.1523-1739.2004.00077.x

Berkes, F. (2012). Sacred Ecology. New York, NY: Routledge. doi: $10.4324 / 9780203123843$

\section{FUNDING}

The Tanoto Foundation supported a learning landscapes workshop in Malinau, Indonesia, in September 2017; The Critical Ecosystems Partnership Fund of the World Bank supported studies on the islands of Seram and Boano where the ideas in this paper were tested.

\section{ACKNOWLEDGMENTS}

The work described in this paper drew heavily on the participation and knowledge of staff of the provincial forestry and planning offices in Ambon and in the Districts of Masohi and Piru. We also acknowledge the patience and forbearance of members of the communities on Boano Island, North Seram, Setulang Village in Malinau District and the numerous industrial and civil society actors in the Kampar Peninsula in Riau Province.

Bhagwat, S., and Humphreys, D. (eds.). (2017). Forest governance in the Anthropocene: a challenge for theory and practice [Special Issue]. Forest Policy and Economics.

Biggs, D., Abel, N., Knight, A. T., Leitch, A., Langston, A., and Ban, N. C. (2011). The implementation crisis in conservation planning: could "mental models" help? Conserv. Lett. 4, 169-183. doi: 10.1111/j.1755-263X.2011. 00170.x

Bixler, R. P. (2014). From community forest management to polycentric governance: assessing evidence from the bottom up. Soc. Nat. Resour. 27, 155-169. doi: 10.1080/08941920.2013.840021

Blythe, J., Silver, J., Evans, L., Armitage, D., Bennett, N. J., Moore, M. L., et al. (2018). The dark side of transformation: latent risks in contemporary sustainability discourse. Antipode 50, 1206-1223. doi: 10.1111/anti.12405

Boedhihartono, A. K. (2012). Visualizing Sustainable Landscapes: Understanding and Negotiating Conservation and Development Trade-Offs Using Visual Techniques. Gland: IUCN.

Boedhihartono, A. K., Bongers, F., Boot, R. G., van Dijk, J., Jeans, H., van Kuijk, M., et al. (2018). Conservation science and practice must engage with the realities of complex tropical landscapes. Trop. Conserv. Sci. 11:1940082918779571. doi: $10.1177 / 1940082918779571$

Brandt, P., Ernst, A., Gralla, F., Luederitz, C., Lang, D. J., Newig, J., et al. (2013). A review of transdisciplinary research in sustainability science. Ecol. Econ. 92, 1-15. doi: 10.1016/j.ecolecon.2013.04.008

Brockhaus, M., Di Gregorio, M., and Carmenta, R. (2014). REDD+ policy networks: exploring actors and power structures in an emerging policy domain. Ecol. Soc. 19:29. doi: 10.5751/ES-07098-190429

Brondizio, E. S. (2017). Interdisciplinarity as Collaborative Problem Framing. Available online at: http://items.ssrc.org/interdisciplinarity-as-collaborativeproblem-framing/

Brondizio, E. S., O’brien, K., Bai, X., Biermann, F., Steffen, W., Berkhout, F., et al. (2016). Re-conceptualizing the anthropocene: a call for collaboration. Glob. Environ. Change 39, 318-327. doi: 10.1016/j.gloenvcha.2016.02.006

Brown, K. (2015). Resilience, Development and Global Change. London: Routledge. doi: 10.4324/9780203498095

Buizer, M., and Turnhout, E. (2011). Text, talk, things, and the subpolitics of performing place. Geoforum 42, 530-538. doi: 10.1016/j.geoforum.2011.05.004

Bull, G., Boedhihartono, A., Bueno, G., Cashore, B., Elliott, C., Langston, J., et al. (2018). Global forest discourses must connect with local forest realities. Int. Forestry Rev. 20, 160-166. doi: 10.1505/146554818823 767573

Butler, J., Wise, R., Skewes, T., Bohensky, E., Peterson, N., Suadnya, W., et al. (2015). Integrating top-down and bottom-up adaptation planning to build adaptive capacity: a structured learning approach. Coast. Manage. 43, 346-364. doi: 10.1080/08920753.2015.1046802 
Cashore, B., Visseren-Hamakers, I., Caro Torres, P., de Jong, W., Denvir, A., Humphreys, D., et al. (2016). Can Legality Verification Enhance Local Rights to Forest Resources? Piloting the Policy Learning Protocol in the Peruvian Forest Context. International Union of Forest Research Organizations (IUFRO) and Yale University's Governance, Environment and Markets (GEM) Initiative.

Chambers, R. (2012). Sharing and co-generating knowledges: reflections on experiences with PRA and CLTS. IDS Bull. 43, 71-87. doi: 10.1111/j.1759-5436.2012.00324.x

Chambers, R. (2014a). Into the Unknown: Explorations in Development Practice. Rugby: Practical Action Publishing.

Chambers, R. (2014b). Knowing in development: a radical agenda for the twenty-first century. Forum. Dev. Stud. 41, 525-537. doi: 10.1080/08039410.2014.959376

Chape, S., Harrison, J., Spalding, M., and Lysenko, I. (2005). Measuring the extent and effectiveness of protected areas as an indicator for meeting global biodiversity targets. Philos. Trans. R. Soc. Lond. B Biol. Sci. 360, 443-455. doi: 10.1098/rstb.2004.1592

Ciampaglia, G. L., Flammini, A., and Menczer, F. (2015). The production of information in the attention economy. Sci. Rep. 5:9452. doi: 10.1038/srep09452

Clark, W. C., Tomich, T. P., van Noordwijk, M., Guston, D., Catacutan, D., Dickson, N. M., et al. (2011). Boundary work for sustainable development: natural resource management at the Consultative Group on International Agricultural Research (CGIAR). Proc. Natl Acad. Sci. U.S.A. 113, 4615-4622. doi: 10.1073/pnas.0900231108

Cleaver, F. (2017). Development Through Bricolage: Rethinking Institutions for Natural Resource Management. London: Routledge. doi: 10.4324/9781315094915

Coe, R., Sinclair, F., and Barrios, E. (2014). Scaling up agroforestry requires research 'in'rather than 'for'development. Curr. Opin. Environ. Sustain. 6, 73-77. doi: 10.1016/j.cosust.2013.10.013

Colglazier, W. (2015). Sustainable development agenda: 2030. Science 349, 1048-1050. doi: 10.1126/science.aad2333

Collier, N., Campbell, B. M., Sandker, M., Garnett, S. T., Sayer, J., and Boedhihartono, A. K. (2011). Science for action: the use of scoping models in conservation and development. Environ. Sci. Policy 14, 628-638. doi: 10.1016/j.envsci.2011.05.004

Cooke, B., and Kothari, U. (2001). Participation: The New Tyranny? London: Zed Books.

Cornell, S., Berkhout, F., Tuinstra, W., Tàbara, J. D., Jäger, J., Chabay, I., et al. (2013). Opening up knowledge systems for better responses to global environmental change. Environ. Sci. Policy 28, 60-70. doi: 10.1016/j.envsci.2012.11.008

Courchamp, F., and Bradshaw, C. J. (2017). 100 articles every ecologist should read. Nat. Ecol. Evol. 1:395.

Danielsen, F., Burgess, N. D., and Balmford, A. (2005). Monitoring matters: examining the potential of locally-based approaches. Biodivers. Conserv. 14, 2507-2542. doi: 10.1007/s10531-005-8375-0

Davenport, M. A., and Anderson, D. H. (2005). Getting from sense of place to place-based management: an interpretive investigation of place meanings and perceptions of landscape change. Soc. Nat. Res. 18, 625-641. doi: 10.1080/08941920590959613

Davenport, T. H., and Beck, J. C. (2001). The Attention Economy: Understanding the New Currency of Business. Boston: Harvard Business Press.

Dawson, N., Martin, A., and Danielsen, F. (2017). Assessing equity in protected area governance: approaches to promote just and effective conservation. Conserv. Lett. 11:e12388. doi: 10.1111/conl.12388

Defries, R., and Rosenzweig, C. (2010). Toward a whole-landscape approach for sustainable land use in the tropics. Proc. Natl. Acad. Sci. U.S.A. 107, 19627-19632. doi: 10.1073/pnas.1011163107

Duit, A., Galaz, V., Eckerberg, K., and Ebbesson, J. (2010). Governance, complexity, and resilience. Glob. Environ. Change 20, 363-368. doi: 10.1016/j.gloenvcha.2010.04.006

Ebrahim, A. (2003). Accountability in practice: mechanisms for NGOs. World Dev. 31, 813-829. doi: 10.1016/S0305-750X(03)00014-7

Enns, C., Bersaglio, B., and Kepe, T. (2014). Indigenous voices and the making of the post-2015 development agenda: the recurring tyranny of participation. Third World Q. 35, 358-375. doi: 10.1080/01436597.2014. 893482
Erbaugh, J., and Agrawal, A. (2017). Clarifying the landscape approach: a letter to the editor on "integrated landscape approaches to managing social and environmental issues in the tropics". Glob. Change Biol. 23, 4453-4454. doi: $10.1111 /$ gcb. 13788

Evans, M. C., Davila, F., Toomey, A., and Wyborn, C. (2017). Embrace complexity to improve conservation decision making. Nat. Ecol. Evol. 1:1588. doi: 10.1038/s41559-017-0345-x

Fischer, J., Meacham, M., and Queiroz, C. (2017). A plea for multifunctional landscapes. Front. Ecol. Environ. 15:59. doi: 10.1002/fee.1464

Fisher, L. A., Kim, Y.-S., Latifah, S., and Mukarom, M. (2017). Managing forest conflicts: perspectives of indonesia's forest management unit directors. Forest Soc. 1, 8-26. doi: 10.24259/fs.v1i1.772

Fisher, M., Moeliono, M., Mulyana, A., Yuliani, E., Adriadi, A., Judda, J., et al. (2018). Assessing the new social forestry project in Indonesia: recognition, livelihood and conservation? Int. Forest. Rev. 20, 346-361. doi: 10.1505/146554818824063014

Friedman, T. L. (2017). Thank You for Being Late: An Optimist's Guide to Thriving in the Age of Accelerations. New York, NY: Picador.

Gallemore, C., Di Gregorio, M., Moeliono, M., Brockhaus, M., and Prasti, H. R. D. (2015). Transaction costs, power, and multi-level forest governance in Indonesia. Ecol. Econ. 114, 168-179. doi: 10.1016/j.ecolecon.2015.03.024

Gaynor, N. (2013). The tyranny of participation revisited: international support to local governance in Burundi. Commun. Dev. J. 49, 295-310. doi: $10.1093 / \mathrm{cdj} / \mathrm{bst} 031$

Giessen, L. (2013). Reviewing the main characteristics of the international forest regime complex and partial explanations for its fragmentation. Int. Forestry Rev. 15, 60-70. doi: 10.1505/146554813805927192

Gilmour, D. (2016). Forty Years of Community-Based Forestry: A Review of its Extent and Effectiveness. FAO Forestry Paper, 176.

Green, K. E., and Lund, J. F. (2015). The politics of expertise in participatory forestry: a case from Tanzania. Forest Policy Econ. 60, 27-34. doi: 10.1016/j.forpol.2014.11.012

Guerrero, A., Bennett, N., Wilson, K., Carter, N., Gill, D., Mills, M., et al. (2018). Achieving the promise of integration in social-ecological research: a review and prospectus. Ecol. Soc. 23:38. doi: 10.5751/ES-10232-230338

Gunarso, P. (2007). Managing Forest Resources in a Decentralized Environment: Lessons Learnt from the Malinau Research Forest, East Kalimantan, Indonesia. Bogor: CIFOR.

Gupta, J., Pouw, N. R., and Ros-Tonen, M. A. (2015). Towards an elaborated theory of inclusive development. Eur. J. Dev. Res. 27, 541-559. doi: $10.1057 /$ ejdr.2015.30

Haider, L. J., Hentati-Sundberg, J., Giusti, M., Goodness, J., Hamann, M., Masterson, V. A., et al. (2018). The undisciplinary journey: earlycareer perspectives in sustainability science. Sustain. Sci. 13, 191-204. doi: $10.1007 /$ s1 1625-017-0445-1

Hajer, M. (2003). Policy without polity? Policy analysis and the institutional void. Policy Sci. 36, 175-195. doi: 10.1023/A:1024834510939

Hodge, I., and Adams, W. M. (2016). Short-term projects versus adaptive governance: conflicting demands in the management of ecological restoration. Land 5:39. doi: 10.3390/land5040039

Horlings, L., Battaglini, E., and Dessein, J. (eds.). (2016). "Introduction: the role of culture in territorialisation," in Cultural Sustainability and Regional Development: Theories and Practices of Territorialisation (Abingdon: Routledge), 1-16.

Huitema, D., and Turnhout, E. (2009). Working at the science-policy interface: a discursive analysis of boundary work at the Netherlands Environmental Assessment Agency. Env. Polit. 18, 576-594. doi: 10.1080/09644010903007427

Humphreys, D., Cashore, B., Visseren-Hamakers, I., Jong, W. D., Mcginley, K., Denvir, A., et al. (2017). Towards durable multistakeholder-generated solutions: the pilot application of a problem-oriented policy learning protocol to legality verification and community rights in Peru. Int. Forest. Rev. 19, 278-293. doi: 10.1505/146554817821865018

IDLO (2016). Connecting the Dots Across the SDGs: Environment, Justice and People - What Can We Learn from Biodiversity Mainstreaming? Rome: International Development Law Organization.

Inman, D. (2016). From the global to the local: the development of indigenous peoples' land rights internationally and in Southeast Asia. Asian J. Int. Law 6, 46-88. doi: 10.1017/S2044251314000356 
Jackson, M. O. (2010). Social and Economic Networks. Princeton: Princeton university press.

Jong, W. D., Katila, P., Galloway, G., and Pacheco, P. (2015). Incentives and constraints of community and smallholder forestry. Forests. 7:209. doi: 10.3390/f7090209

Keeley, J., and Scoones, I. (2014). Understanding Environmental Policy Processes: Cases from Africa. London: Routledge. doi: 10.4324/9781849773621

Khadka, C., and Vacik, H. (2008). "Applying adaptive collaborative management for social learning: a case study of community forestry in Nepal," in Proceedings of I-Know (Graz), 101-108.

Khatun, K., Gross-Camp, N., Corbera, E., Martin, A., Ball, S., and Massao, G. (2015). When participatory forest management makes money: insights from Tanzania on governance, benefit sharing, and implications for REDD+. Environ. Plann. A 47, 2097-2112. doi: 10.1177/0308518X155 95899

Knight, A. T., Cowling, R. M., Rouget, M., Balmford, A., Lombard, A. T., and Campbell, B. M. (2008). Knowing but not doing: selecting priority conservation areas and the research-implementation gap. Conserv. Biol. 22, 610-617. doi: 10.1111/j.1523-1739.2008.00914.x

Kowalski, A. A., and Jenkins, L. D. (2015). The role of bridging organizations in environmental management: examining social networks in working groups. Ecol. Soc. 20. doi: 10.5751/ES-07541-200216

Kusters, K. (2015). Climate-Smart Landscapes and The Landscape ApproachAn Exploration of the Concepts and Their Practical Implications. Tropenbos International, Wageningen Google Scholar.

Kusters, K., Buck, L., De Graaf, M., Minang, P., van Oosten, C., and Zagt, R. (2018). Participatory planning, monitoring and evaluation of multi-stakeholder platforms in integrated landscape initiatives. Environ. Manage. 62, 170-181. doi: 10.1007/s00267-017-0847-y

Lang, D. J., Wiek, A., Bergmann, M., Stauffacher, M., Martens, P., Moll, P., et al. (2012). Transdisciplinary research in sustainability science: practice, principles, and challenges. Sustain. Sci. 7, 25-43. doi: 10.1007/s11625-011-0149-x

Langston, J., Riggs, R., Sururi, Y., Sunderland, T., and Munawir, M. (2017). Estate crops more attractive than community forests in West Kalimantan, Indonesia. Land 6:12. doi: 10.3390/land6010012

Langston, J. D., Mcintyre, R., Falconer, K., Sunderland, T., van Noordwijk, M., and Boedhihartono, A. K. (2019). Discourses mapped by Q-method show governance constraints motivate landscape approaches in Indonesia. PLoS ONE 14:e0211221. doi: 10.1371/journal.pone.0211221

Laurance, W. F., Kakul, T., Keenan, R. J., Sayer, J., Passingan, S., Clements, G. R., et al. (2011). Predatory corporations, failing governance, and the fate of forests in Papua New Guinea. Conserv. Lett. 4, 95-100. doi: 10.1111/j.1755-263X.2010.00156.x

Law, E. A., Bryan, B. A., Meijaard, E., Mallawaarachchi, T., Struebig, M. J., Watts, M. E., et al. (2017). Mixed policies give more options in multifunctional tropical forest landscapes. J. Appl. Ecol. 54, 51-60. doi: 10.1111/1365-2664. 12666

Liswanti, N. (2012). Building A Shared Vision: Scenarios for Collaborative Land Use Planning in Central Moluccas Regency, Indonesia. The Futures of Agriculture. Brief No. 39 - English. Rome: Global Forum on Agricultural Research (GFAR).

Liu, J., Dietz, T., Carpenter, S. R., Alberti, M., Folke, C., Moran, E., et al. (2007). Complexity of coupled human and natural systems. Science 317, 1513-1516. doi: 10.1126/science.1144004

Lund, J. F. (2015). Paradoxes of participation: the logic of professionalization in participatory forestry. Forest Policy Econ. 60, 1-6. doi: 10.1016/j.forpol.2015.07.009

Marmot, M. G. (2004). Evidence based policy or policy based evidence? Willingness to take action influences the view of the evidence-look at alcohol. BMJ 328:906. doi: 10.1136/bmj.328.7445.906

Massey, D. (2005). For Space. Thousand Oaks, CA: Sage.

Mauser, W., Klepper, G., Rice, M., Schmalzbauer, B. S., Hackmann, H., Leemans, R., et al. (2013). Transdisciplinary global change research: the co-creation of knowledge for sustainability. Curr. Opin. Environ. Sustain. 5, 420-431. doi: 10.1016/j.cosust.2013.07.001

Mccall, M. K. (2016). Beyond "Landscape" in REDD+: the imperative for “Territory”. World Dev. 85, 58-72. doi: 10.1016/j.worlddev.2016.05.001

Mckeown, B., and Thomas, D. B. (2013). Q Methodology. Los Angeles: Sage publications.
Mcnie, E. C. (2007). Reconciling the supply of scientific information with user demands: an analysis of the problem and review of the literature. Environ. Sci. Policy 10, 17-38. doi: 10.1016/j.envsci.2006.10.004

Mintzberg, H. (1994). Rise and Fall of Strategic Planning. New York, NY: Simon and Schuster.

Mintzberg, H., and Westley, F. (2001). Decision making: It's not what you think. MIT Sloan Manage. Rev. 42:89.

Moreno, L. A. (2016). "If you want to tackle carbon emissions let indigenous people control their land," in The Guardian (Washington, DC: International Edition).

Nagendra, H., and Ostrom, E. (2012). Polycentric governance of multifunctional forested landscapes. Int. J. Commons 6, 104-133. doi: 10.18352/ijc.321

Nel, J. L., Roux, D. J., Driver, A., Hill, L., Maherry, A. C., Snaddon, K., et al. (2016). Knowledge co-production and boundary work to promote implementation of conservation plans. Conserv. Biol. 30, 176-188. doi: 10.1111/cobi.12560

Nijnik, M., Nijnik, A., Bergsma, E., and Matthews, R. (2014). Heterogeneity of experts' opinion regarding opportunities and challenges of tackling deforestation in the tropics: a Q methodology application. Mitig. Adapt. Strateg. Glob. Change 19, 621-640. doi: 10.1007/s11027-013-9529-0

Opdam, P. (2018). Exploring the role of science in sustainable landscape management. an introduction to the special issue. Sustainability 10, 1-6. doi: $10.3390 /$ su10020331

Ostrom, E. (2015). Governing the Commons. Cambridge: Cambridge University Press. doi: 10.1017/CBO9781316423936

Pawson, R. (2006). Evidence-Based Policy: A Realist Perspective. London: Sage.

Peres, C. A. (2011). Conservation in sustainable-use tropical forest reserves. Conserv. Biol. 25, 1124-1129. doi: 10.1111/j.1523-1739.2011.01770.x

Persha, L., and Andersson, K. (2014). Elite capture risk and mitigation in decentralized forest governance regimes. Glob. Environ. Change 24, 265-276. doi: 10.1016/j.gloenvcha.2013.12.005

Pielke, R. A. Jr. (2007). The Honest Broker: Making Sense of Science in Policy and Politics. Cambridge: Cambridge University Press. doi: $10.1017 / \mathrm{CBO} 9780511818110$

Pirard, R., Petit, H., Baral, H., and Achdiawan, R. (2016). Perceptions of local people toward pulpwood plantations: insights from the Q-method in Indonesia. Int. Forest. Rev. 18, 218-230. doi: 10.1505/146554816818966327

Polk, M. (2014). Achieving the promise of transdisciplinarity: a critical exploration of the relationship between transdisciplinary research and societal problem solving. Sustain. Sci. 9, 439-451. doi: 10.1007/s11625-014-0247-7

Popa, F., Guillermin, M., and Dedeurwaerdere, T. (2015). A pragmatist approach to transdisciplinarity in sustainability research: from complex systems theory to reflexive science. Futures 65, 45-56. doi: 10.1016/j.futures.2014.02.002

Pressey, R. L., Weeks, R., and Gurney, G. G. (2017). From displacement activities to evidence-informed decisions in conservation. Biol. Conserv. 212, 337-348. doi: 10.1016/j.biocon.2017.06.009

Redford, K. H., Padoch, C., and Sunderland, T. (2013). Fads, funding, and forgetting in three decades of conservation. Conserv. Biol. 27, 437-438. doi: $10.1111 /$ cobi.12071

Reed, J., van Vianen, J., Barlow, J., and Sunderland, T. (2017). Have integrated landscape approaches reconciled societal and environmental issues in the tropics? Land Use Policy 63, 481-492. doi: 10.1016/j.landusepol.2017.02.021

Reed, J., van Vianen, J., Deakin, E. L., Barlow, J., and Sunderland, T. (2016). Integrated landscape approaches to managing social and environmental issues in the tropics: learning from the past to guide the future. Glob. Change Biol. 22, 2540-2554. doi: 10.1111/gcb.13284

Riggs, R. A., Langston, J. D., Margules, C., Boedhihartono, A. K., Lim, H. S., Sari, D. A., et al. (2018a). Governance challenges in an Eastern Indonesian Forest Landscape. Sustainability 10:169. doi: 10.3390/su10010169

Riggs, R. A., Langston, J. D., and Sayer, J. (2018b). Incorporating governance into forest transition frameworks to understand and influence Cambodia's forest landscapes. Forest Policy Econ. 96, 19-27. doi: 10.1016/j.forpol.2018.08.003

Riggs, R. A., Sayer, J., Margules, C., Boedhihartono, A. K., Langston, J. D., and Sutanto, H. (2016). Forest tenure and conflict in Indonesia: contested rights in Rempek Village, Lombok. Land Use Policy 57, 241-249. doi: 10.1016/j.landusepol.2016.06.002

Rights and Resources Initiative (2014). Lots of Words, Little Action: Will the Private Sector Tip the Scales for Community Land Rights. Washington, DC: Rights and Resources Initiative. 
Robinson, J. G. (2006). Conservation biology and real-world conservation. Conserv. Biol. 20, 658-669. doi: 10.1111/j.1523-1739.2006. 00469.x

Ros-Tonen, M. A., Reed, J., and Sunderland, T. (2018). From synergy to complexity: the trend toward integrated value chain and landscape governance. Environ. Manage. 62, 1-14. doi: 10.1007/s00267-018-1055-0

Sahide, M. A. K., and Giessen, L. (2015). The fragmented land use administration in Indonesia-Analysing bureaucratic responsibilities influencing tropical rainforest transformation systems. Land Use Policy 43, 96-110. doi: 10.1016/j.landusepol.2014.11.005

Sayer, J., and Campbell, B. M. (2004). The Science of Sustainable Development: Local Livelihoods and the Global Environment. Cambridge: Cambridge University Press.

Sayer, J., Endamana, D., Boedhihartono, A., Ruiz Pérez, M., and Breuer, T. (2016b). "Learning from change in the Sangha Tri-national landscape," in International Forestry Review Special Issue: Valuing the Cameroonian Forest, Vol. 18, 130-139.

Sayer, J., and Margules, C. (2017). Biodiversity in locally managed lands. Land 6:41. doi: 10.3390/land6020041

Sayer, J., Margules, C., Bohnet, I., Boedhihartono, A., Pierce, R., Dale, A., et al. (2015). The role of citizen science in landscape and seascape approaches to integrating conservation and development. Land 4, 1200-1212. doi: $10.3390 /$ land 4041200

Sayer, J., Sunderland, T., Ghazoul, J., Pfund, J.-L., Sheil, D., Meijaard, E., et al. (2013). Ten principles for a landscape approach to reconciling agriculture, conservation, and other competing land uses. Proc. Natl. Acad. Sci. U.S.A. 110, 8349-8356. doi: 10.1073/pnas.1210595110

Sayer, J. A., Margules, C., Boedhihartono, A. K., Sunderland, T., Langston, J. D., Reed, J., et al. (2016a). Measuring the effectiveness of landscape approaches to conservation and development. Sustain. Sci. 12, 465-476. doi: $10.1007 / \mathrm{s} 11625-016-0415-\mathrm{Z}$

Scheba, A., and Mustalahti, I. (2015). Rethinking 'expert' knowledge in community forest management in Tanzania. Forest Policy Econ. 60, 7-18. doi: 10.1016/j.forpol.2014.12.007

Schmitt, C. B., Burgess, N. D., Coad, L., Belokurov, A., Besançon, C., Boisrobert, L., et al. (2009). Global analysis of the protection status of the world's forests. Biol. Conserv. 142, 2122-2130. doi: 10.1016/j.biocon.2009.04.012

Schusser, C., Mcdermott, M., and Dressler, W., (eds.). (2015). "The politics of community forestry in a global age - a critical analysis," in Forest Policy and Economics. 58, 1-4. doi: 10.1016/j.forpol.2015.04.006

Scott, J. C. (1998). Seeing Like a State: How Certain Schemes to Improve the Human Condition Have Failed. New Haven: Yale University Press.

Shanahan, E. A., Jones, M. D., and Mcbeth, M. K. (2011). Policy narratives and policy processes. Policy Stud. J. 39, 535-561. doi: 10.1111/j.1541-0072.2011.00420.x

Sheil, D. (2017). "Exploring local perspectives and preferences in forest landscapes: towards democratic conservation," in Tropical Forest Conservation: Long-Term Processes of Human Evolution, Cultural Adaptations and Consumption Patterns, eds N. Sanz, R. C. Lewis, J. P. Mata, and C. Connaughton (Ciudad de Mexico: UNESCO), 262-283.

Sikor, T. (ed.). (2006). Community-Based Forestry in the Developing World: Analyses from an Agrarian Perspective [Special Issue]. Forest Policy and Economics.

Singer, B., and Giessen, L. (2017). Towards a donut regime? Domestic actors, climatization, and the hollowing-out of the international forests regime in the Anthropocene. Forest Policy Econ. 79, 69-79. doi: 10.1016/j.forpol.2016.11.006

Sundar, N. (2000). Unpacking the 'joint' in joint forest management. Dev. Change 31, 255-279. doi: 10.1111/1467-7660.00154

Sunderland, T. C., Ehringhaus, C., and Campbell, B. (2007). Conservation and development in tropical forest landscapes: a time to face the trade-offs? Environ. Conserv. 34, 276-279. doi: 10.1017/S0376892908004438

Sutherland, W. J., Roy, D. B., and Amano, T. (2015). An agenda for the future of biological recording for ecological monitoring and citizen science. Biol. J. Linn. Soc. 115, 779-784. doi: 10.1111/bij.12576
Tengö, M., Hill, R., Malmer, P., Raymond, C. M., Spierenburg, M., Danielsen, F., et al. (2017). Weaving knowledge systems in IPBES, CBD and beyondlessons learned for sustainability. Curr. Opin. Environ. Sustain. 26, 17-25. doi: 10.1016/j.cosust.2016.12.005

Terborgh, J., and Peres, C. A. (2017). Do community-managed forests work? A biodiversity perspective. Land 6:22. doi: 10.3390/land6020022

Thornton, P. K., Schuetz, T., Förch, W., Cramer, L., Abreu, D., Vermeulen, S., et al. (2017). Responding to global change: a theory of change approach to making agricultural research for development outcome-based. Agric. Syst. 152, 145-153. doi: 10.1016/j.agsy.2017.01.005

Tschirhart, C., Mistry, J., Berardi, A., Bignante, E., Simpson, M., Haynes, L., et al. (2016). Learning from one another: evaluating the impact of horizontal knowledge exchange for environmental management and governance. Ecol. Soc. 21. doi: 10.5751/ES-08495-210241

Tufekci, Z. (2013). "Not this one" social movements, the attention economy, and microcelebrity networked activism. Am. Behav. Sci. 57, 848-870. doi: $10.1177 / 0002764213479369$

Union of Concerned Scientists (2013). Who Owns The Forest. ususa.org. Available online at: http://www.ucsusa.org/news/press_release/who- owns- theforest-0387.html\#.WWgtCsZ7GV6 [Accessed 2017].

Valverde, M. (2007). Reassembling the Social: An Introduction to Actor-Network Theory. Malden, MA: Blackwell Publishing.

van Noordwijk, M. (2017). Integrated natural resource management as pathway to poverty reduction: innovating practices, institutions and policies. Agric. Syst. doi: 10.1016/j.agsy.2017.10.008

van Noordwijk, M., Minang, P. A., Freeman, O. E., Mbow, C., and De Leeuw, J. (2015). "The future of landscape approaches: interacting theories of place and change," in Climate-Smart Landscapes: Multifunctionality in Practice, eds P. A. Minang, M. van Noordwijk, O. E. Freeman, C. Mbow, J. de Leeuw, D. Catacutan (Nairobi: World Agroforestry Centre (ICRAF)), 375-387.

van Oosten, C., Moeliono, M., and Wiersum, F. (2017). From product to placespatializing governance in a commodified landscape. Environ. Manage. 62, 157-169. doi: 10.1007/s00267-017-0883-7

Wiek, A., Ness, B., Schweizer-Ries, P., Brand, F. S., and Farioli, F. (2012). From complex systems analysis to transformational change: a comparative appraisal of sustainability science projects. Sustain. Sci. 7, 5-24. doi: 10.1007/s11625-011-0148-y

Wiek, A., Withycombe, L., and Redman, C. L. (2011). Key competencies in sustainability: a reference framework for academic program development. Sustai. Sci. 6, 203-218. doi: 10.1007/s11625-0110132-6

Wiersum, K. F., Lescuyer, G., Nketiah, K. S., and Wit, M. (eds.). (2013). Emerging Forest Regimes [Special Issue]. Forest Policy and Economics.

Wollenberg, E., Iwan, R., Limberg, G., Moeliono, M., Rhee, S., and Sudana, M. (2007). Facilitating cooperation during times of chaos: spontaneous orders and muddling through in Malinau District, Indonesia. Ecol. Soc. 12:3. doi: 10.5751/ES-01943-120103

Wunder, S., Campbell, B., Frost, P. G., Sayer, J. A., Iwan, R., and Wollenberg, L. (2008). When donors get cold feet: the community conservation concession in Setulang (Kalimantan, Indonesia) that never happened. Ecol. Soc. 12:3. doi: 10.5751/ES-02376-130112

Conflict of Interest Statement: The authors declare that the research was conducted in the absence of any commercial or financial relationships that could be construed as a potential conflict of interest.

Copyright (๑) 2019 Langston, Riggs, Kastanya, Sayer, Margules and Boedhihartono. This is an open-access article distributed under the terms of the Creative Commons Attribution License (CC BY). The use, distribution or reproduction in other forums is permitted, provided the original author(s) and the copyright owner(s) are credited and that the original publication in this journal is cited, in accordance with accepted academic practice. No use, distribution or reproduction is permitted which does not comply with these terms. 